Article

\title{
Chemical Composition of Winter Rape Seeds Depending on the Biostimulators Used
}

\author{
Marek Gugała ${ }^{1}$, Anna Sikorska ${ }^{2, *}$, Krystyna Zarzecka ${ }^{1}$, Pavol Findura ${ }^{3,4}$ and \\ Urszula Malaga-Toboła 4
}

1 Faculty of Agrobioengineering and Animal Husbandry, University of Natural Sciences and Humanities in Siedlce, ul. Prusa 14, 08-110 Siedlce, Poland; gugala@uph.edu.pl (M.G.);

krystyna.zarzecka@uph.edu.pl (K.Z.)

2 Department of Agriculture, Vocational State School of Ignacy Mościcki in Ciechanów, ul. Narutowicza 9, 06-400 Ciechanów, Poland

3 Department of Biosystems Engineering; Slovak University of Agriculture Nitra, Tr. A. Hlinku 2, 949-76 Nitra, Slovak Republic; pavol.findura@uniag.sk

4 Faculty of Production and Power Engineering; University of Agriculture in Krakow, ul. Balicka 116B, 30-149 Krakow, Poland; Urszula.Malaga-Tobola@ur.krakow.pl

* Correspondence: anna.sikorska@puzim.edu.pl; Tel.: +48(23)672-30-75

Received: 21 October 2019; Accepted: 4 November 2019; Published: 5 November 2019

\begin{abstract}
Plant growth regulators may reduce the negative effect of environmental stress factors and can contribute to increasing the quality and quantity of the yield. The aim of the research was to determine the effect of biostimulators on the quality of seeds of three winter rape morphotypes. Three varieties of winter rape were used: Poznaniak (population variety), PX104 (hybrid variety restored with a semi-dwarf growth type) and Konkret (hybrid variety restored with a traditional growth type). The varieties were exposed to three treatments: the biostimulator Tytanit ${ }^{\circledR}$, the biostimulator Asahi ${ }^{\circledR}$ SL and the biostimulator Silvit ${ }^{\circledR}$, and the control with no biostimulators. Seeds were analysed for content of crude fat, total fat and crude fibres. The biostimulators reduced total protein content (on average from 0.8 to $1.75 \mathrm{~g} \cdot \mathrm{kg}^{-1}$ of d.m.) and increased the concentration of crude fat (on average from 0.71 to $1.93 \mathrm{~g} \cdot \mathrm{kg}^{-1} \mathrm{of} \mathrm{d.m}$.) and crude fibre (on average from 0.15 to $0.84 \mathrm{~g} \cdot \mathrm{kg}^{-1}$ of d.m.) compared to the control. PX104 had the highest content of crude fat and total fat protein, and the lowest in crude fibre. The smallest protein content was found in seeds of the long-stem hybrid Konkret, while crude fat was lowest in the population form (Poznaniak), and crude fibre was lowest in long-stem hybrid (Konkret).
\end{abstract}

Keywords: anti-nutritional substances; fat; fibre; morphotype; protein

\section{Introduction}

Rapeseed (Brassica napus L. var. oleifera) is one of the most important oil-protein crops grown in the world. One of the many factors with a negative effect on the quantity and quality of rapeseed crops include unfavourable soil conditions and drought-related stress. Strong stress leads to damaged cell structures and disturbances in metabolism and as a result, can lead to photosynthesis and plant and metabolism disruption [1]. Rouphael and Colla [2] reports that plant biostimulators are products obtained from various organic or inorganic substances or microorganisms that improve plant growth, productivity and reduce the negative effects of environmental stress. Many authors [3-8] have shown that regulators of plant growth and development reduce the negative impact of abiotic stress factors. Petrozza et al. [9] showed that when a plant experiences stress, the biostimulator strengthens its stress tolerance mechanism. 
Colla and Rouphael [10] and Rouphael et al. [11] emphasize that the use of biostimulators is increasingly becoming one of the basic elements of agricultural technology in many crop species around the world. Calvo et al. [12] forecast that the global market for biostimulants in consumption will increase by $14 \%$ per year.

According to El-Boray et al. [13], Przybysz et al. [14], Kocira et al. [15] and Zulfiqar et al. [16], preparations stimulating plant growth can be based on extracts of marine algae, free amino acids, humic compounds, effective microorganisms or phenolic compounds. Their use in plant cultivation has a positive effect on photosynthesis, regulation of water management and increasing the content of organic and inorganic compounds, which in turn, has a positive effect on the size and quality of the crop.

Grabowska et al. [17] and Kolomaznik et al. [18] stated that the effectiveness of biostimulators depends on many factors, including the correct selection of preparations, their dose, concentration and methods of application, as well as plant species and varieties and environmental factors.

The study assumes the hypothesis that the use of biostimulators may have a positive effect on the chemical composition of winter rapeseeds.

Due to few studies being available on the beneficial effects of growth bioregulators on the quality characteristics of winter rapeseed, and the wide interest in agricultural practice, research was undertaken to determine the effect of biostimulators on the chemical composition of three winter rapeseed varieties.

\section{Materials and Methods}

\subsection{Arrangement of the Experiment and Research Location}

The field experiment was carried out in 2013-2016 in three different fields at the Agricultural Experimental Station-Zawady $\left(52^{\circ} 03^{\prime} \mathrm{N} ; 22^{\circ} 33^{\prime} \mathrm{E}\right)$, belonging to the University of Natural Sciences and Humanities in Siedlce. The experiment was established in a random split-plot system in three repetitions (total number of plots $3 \times 4=12$, repeated in 3 successive crop rotations from 2013-2016). The surface of one plot was $21 \mathrm{~m}^{-2}$. The examined factors were:

I-three varieties of winter rape: Poznaniak (population variety), PX104 (hybrid variety restored with a semi-dwarf growth type) and Konkret (hybrid variety restored with a traditional growth type).

II-four types of biostimulators:

1. control-no biostimulators;

2. biostimulator Tytanit ${ }^{\circledR}$ (active substance-titanium), applied in three doses of $0.20 \mathrm{dm}^{3} \mathrm{ha}^{-1}$ in the autumn (2 October 2013, 6 October 2014, 5 October 2015) at the 4-8 leaf stage (BBCH 14-18) according to the rating of Biologische Bundesantalt, Bundessortenamt and Chemische Industrie (BBCH), in the spring (26 March 2014, 23 March 2015, 21 March 2016) after the onset of growth (BBCH 21-36), and at the budding stage-early flowering (30 April 2014, 29 April 2015,4 May 2016) (BBCH 50-61) [19];

3. biostimulator Asahi ${ }^{\circledR}$ SL (active substances: sodium orto nitrophenol, sodium para nitrophenol, sodium 5-nitroguaiacolate), applied in three doses of $0.60 \mathrm{dm}^{3} \cdot \mathrm{ha}^{-1}$ in the autumn (25 September 2013, 29 September 2014, 27 September 2015) at the stage of 3-5 leaves (BBCH 13-15), in the spring (26 March 2014, 23 March 2015, 21 March 2016) after the plants resumed growth (BBCH 28-30), and two weeks following the second application (10 April 2014, 7 April 2015, 4 April 2016);

4. biostimulator Silvit ${ }^{\circledR}$ (active substances: active silicon, potassium oxide, boron, zinc), applied in three doses of $0.20 \mathrm{dm}^{3} \cdot \mathrm{ha}^{-1}$, three weeks after emergence (2 October 2013, 6 October 2014, 5 October 2015) (BBCH 12-14), in spring (26 March 2014, 23 March 2015, 21 March 2016) after plants resumed growth (BBCH 28-30), and two weeks after the second application (10 April 2014, 7 April 2015, 4 April 2016).

The studies were carried out on soil classified according to WBR FAO (2014) [20] as the Haplic Luvisols group - sandy, belonging to a very good rye soil complex of the IVb botanical class. In the years of the experiment, the soil reaction $(\mathrm{pH})$ ranged from 5.68 to 5.75 . The soil was characterised 
by a low total nitrogen content (average from 0.80 to $0.90 \mathrm{~g} \cdot \mathrm{kg}^{-1}$ ), phosphorus content (average from 0.33 to $0.55 \mathrm{~g} \cdot \mathrm{kg}^{-1}$ ), potassium content (average from 0.61 to $0.67 \mathrm{~g} \cdot \mathrm{kg}^{-1}$ ) calcium content (average from 0.82 to $0.85 \mathrm{~g} \cdot \mathrm{kg}^{-1}$ ), magnesium content (average from 0.38 to $0.46 \mathrm{~g} \cdot \mathrm{kg}^{-1}$ ) and sulphur content (average from 0.11 to $0.15 \mathrm{~g} \cdot \mathrm{kg}^{-1}$ ). It has a low abundance in assimilable forms of phosphorus (average from 75.0 to $80 . \mathrm{g} \cdot \mathrm{kg}^{-1}$ ) and an average assimilability of potassium (from 200.0 to $205.0 \mathrm{~g} \cdot \mathrm{kg}^{-1}$ ) and magnesium (average from 59.0 to $61.0 \mathrm{~g} \cdot \mathrm{kg}^{-1}$ ).

The phosphorus and potassium fertilization at the dose of $40.0 \mathrm{~kg} \mathrm{P} \cdot \mathrm{ha}^{-1}$ and $110.0 \mathrm{~kg} \mathrm{~K} \cdot \mathrm{ha}^{-1}$ with the first dose of $40.0 \mathrm{~kg} \mathrm{~N} \cdot \mathrm{ha}^{-1}$ was used before sowing. Fertilization was used in the form of Lubofos for Rape at the dose of $600.0 \mathrm{~kg}$, i.e., $21.0 \mathrm{~kg} \mathrm{~N} \cdot \mathrm{ha}^{-1}, 26.4 \mathrm{~kg} \mathrm{P} \cdot \mathrm{ha}^{-1}, 92.1 \mathrm{~kg} \mathrm{~K} \cdot \mathrm{ha}^{-1}, 34.8 \mathrm{~kg} \mathrm{~S} \cdot \mathrm{ha}^{-1}, 1.2 \mathrm{~kg}$ $\mathrm{B} \cdot \mathrm{ha}^{-1}$. Fertilization rates were supplemented by $55.9 \mathrm{~kg} \cdot \mathrm{ha}^{-1}$ of ammonium nitrate $\left(19.0 \mathrm{~kg} \mathrm{~N} \cdot \mathrm{ha}^{-1}\right)$, $29.6 \mathrm{~kg} \cdot \mathrm{ha}^{-1}$ of triple superphosphate $\left(13.6 \mathrm{~kg} \mathrm{P} \cdot \mathrm{ha}^{-1}\right)$ and $29 \mathrm{~kg} \cdot \mathrm{ha}^{-1}$ of potassium salt $\left(17.9 \mathrm{~kg} \mathrm{~K} \cdot \mathrm{ha}^{-1}\right)$. The second nitrogen dose of $100.0 \mathrm{~kg} \cdot \mathrm{ha}^{-1}$ was applied in spring before vegetation using ammonium nitrate at the dose of $255.5 \mathrm{~kg} \cdot \mathrm{ha}^{-1}$ and ammonium sulphate at the dose of $62.5 \mathrm{~kg} \cdot \mathrm{ha}^{-1}$. The third dose of nitrogen $60.0 \mathrm{~kg} \cdot \mathrm{ha}^{-1}$ was applied at the beginning of budding using ammonium nitrate at the dose of $176.5 \mathrm{~kg} \cdot \mathrm{ha}^{-1}$.

The three crops of rapeseed were harvested on 11 July 2014, 17 July 2015 and 14 July 2016, respectively.

\subsection{Chemical Analysis of Seeds}

The tests samples of winter rape seeds were analyzed for:

Crude fat ( $\mathrm{g} \cdot \mathrm{kg}^{-1}$ of d.m.) - with the Soxhlet method, which extracted the fat with petroleum ether in a Soxhlet apparatus and determides its quantity by weight, total protein $\left(\mathrm{g} \cdot \mathrm{kg}^{-1} \mathrm{of} \mathrm{d.m.)} \mathrm{[21].}\right.$

Total protein ( $\mathrm{g} \cdot \mathrm{kg}^{-1}$ of d.m.) - with the Kjeldahl method where protein nitrogen was converted to ammonium sulphate with concentrated sulphuric acid in the presence of a catalyst, the solution was alkalised, distilled and titrated with hydrochloric acid-ammonia bound with boric acid, the conversion factor Nx6.25 was used, crude fibre (g. $\mathrm{kg}^{-1}$ of d.m.) [22].

Crude fibres $\left(\mathrm{g} \cdot \mathrm{kg}^{-1}\right.$ of $\mathrm{d}$.m.) - with the Wenden method consisting of the quantitative determination of organic substances insoluble during cooking in an acid solution.

\subsection{Statistical Analysis}

Research results were statistically analysed by ANOVA. The results of the study were statistically analysed using the analysis of variance. The significance of the sources of variation was tested by the Fischer-Snedecor " $\mathrm{F}$ " test, and the assessment of significance of differences at the significance level $p<0.05$ between the compared averages used Tukey's multiple intervals. Statistical calculations were made based on our own algorithm written in Excel [23].

\subsection{Weather Conditions}

Climatic data from 2013-2016 was obtained from the Hydrological and Meteorological Station in Siedlce. During the years of conducting the experiment, varied weather conditions prevailed (Table 1). In the second growing season, the largest annual rainfall was recorded (average of $599.2 \mathrm{~mm}$ ) and the smallest mean annual air temperature (average of $8.8^{\circ} \mathrm{C}$ ). In this period, the annual amount of rainfall was $171.7 \mathrm{~mm}$ higher compared to the long-term period. The last year of tests was the warmest and most dry. The annual rainfall was $43.8 \mathrm{~mm}$ lower than the average for the long-term period, and the average air temperature was higher by $1.3^{\circ} \mathrm{C}$ compared to the average from 1996-2010. Based on the calculated Sielianinov hydrothermal coefficient, the first and last year of the study were optimal, while the growing season 2014-2015 was rather wet $(K=1.71)$. 
Table 1. Characteristics of weather conditions in the years 2013-2016 (Poland).

\begin{tabular}{|c|c|c|c|c|c|c|c|c|}
\hline \multirow{3}{*}{ Months } & \multicolumn{4}{|c|}{ Rainfalls (mm) } & \multicolumn{4}{|c|}{ Air Temperature $\left({ }^{\circ} \mathrm{C}\right)$} \\
\hline & \multirow{2}{*}{$\begin{array}{c}\text { Multiyear Sum } \\
1996-2010\end{array}$} & \multicolumn{3}{|c|}{ Monthly Sum } & \multirow{2}{*}{$\begin{array}{c}\text { Multiyear Mean } \\
1996-2010\end{array}$} & \multicolumn{3}{|c|}{ Monthly Mean } \\
\hline & & 2013-2014 & 2014-2015 & 2015-2016 & & 2013-2014 & 2014-2015 & 2015-2016 \\
\hline VIII & 59.9 & 15.0 & 105.7 & 11.9 & 18.5 & 18.8 & 18.1 & 21.0 \\
\hline IX & 42.3 & 94.3 & 26.3 & 47.1 & 13.5 & 11.7 & 14.1 & 14.5 \\
\hline$x$ & 24.2 & 32.8 & 3.0 & 37.0 & 7.9 & 9.3 & 8.5 & 6.5 \\
\hline XI & 20.2 & 34.7 & 32.5 & 42.2 & 4.0 & 5.1 & 3.4 & 4.7 \\
\hline XII & 18.6 & 15.4 & 90.4 & 16.5 & -0.1 & 1.2 & 0.1 & 3.7 \\
\hline I & 19.0 & 28.6 & 51.4 & 10.9 & -3.2 & -4.5 & 0.6 & -4.5 \\
\hline II & 16.0 & 34.0 & 0.7 & 29.0 & -2.3 & 0.7 & 0.7 & 2.5 \\
\hline III & 18.3 & 29.6 & 53.1 & 33.5 & 2.4 & 5.8 & 4.6 & 3.5 \\
\hline IV & 33.6 & 45.0 & 30.0 & 28.7 & 8.0 & 9.8 & 8.2 & 9.1 \\
\hline $\mathrm{V}$ & 58.3 & 92.7 & 100.2 & 54.8 & 13.5 & 13.5 & 12.3 & 15.1 \\
\hline VI & 59.6 & 55.4 & 43.3 & 36.9 & 17.0 & 15.4 & 16.5 & 18.4 \\
\hline VII & 57.5 & 10.0 & 62.6 & 35.2 & 19.7 & 20.8 & 18.7 & 19.1 \\
\hline VIII-VII & 427.5 & 487.5 & 599.2 & 383.7 & 8.2 & 9.0 & 8.8 & 9.5 \\
\hline \multicolumn{9}{|c|}{ Sielianinovs hydrothermic coefficients * } \\
\hline & & & \multicolumn{2}{|c|}{$2013-2014$} & \multicolumn{2}{|c|}{ 2014-2015 } & \multicolumn{2}{|c|}{ 2015-2016 } \\
\hline & VIII & & \multicolumn{2}{|c|}{0.31} & \multicolumn{2}{|c|}{1.87} & \multicolumn{2}{|c|}{0.20} \\
\hline & IX & & \multicolumn{2}{|c|}{2.63} & \multicolumn{2}{|c|}{0.66} & \multicolumn{2}{|c|}{1.20} \\
\hline & $x$ & & \multicolumn{2}{|c|}{1.01} & \multicolumn{2}{|c|}{0.22} & \multicolumn{2}{|c|}{2.15} \\
\hline & III & & \multicolumn{2}{|c|}{1.48} & \multicolumn{2}{|c|}{4.63} & \multicolumn{2}{|c|}{3.49} \\
\hline & IV & & \multicolumn{2}{|c|}{1.41} & \multicolumn{2}{|c|}{1.35} & \multicolumn{2}{|c|}{1.07} \\
\hline & V & & \multicolumn{2}{|c|}{2.33} & \multicolumn{2}{|c|}{2.91} & \multicolumn{2}{|c|}{1.47} \\
\hline & VI & & \multicolumn{2}{|c|}{1.23} & \multicolumn{2}{|c|}{0.84} & & \\
\hline & VII & & & & & & & \\
\hline & VIII-VII & & & & & & & \\
\hline
\end{tabular}
$2.5<\mathrm{k} \leq 3.0$, extremely humid $\mathrm{k}>3.0$. 


\section{Results and Discussion}

\subsection{The Content of Total Protein Depending on the Types of Biostimulators Used}

Our own research showed that biostimulators significantly affected the reduction of total protein content in rapeseeds (Table 2). The smallest concentration was recorded on object 4, sprayed with the Silvit biostimulator. This value was lower on average by $1.75 \mathrm{~g} \cdot \mathrm{kg}^{-1} \mathrm{of} \mathrm{d} . \mathrm{m}$. compared to the control variant. Different results were obtained by Gugała et al. [25], who did not find a significant effect of the biostimulators Tytanit, Asahi SL or Silvit for the value of this feature. Similarly, Jarecki and Bobrecka-Jamro [26,27], Kozak et al. [28] and Matysiak et al. [29,30] did not prove the effect of bioregulators and foliar fertilizers containing micro- and macro-elements for the value of this feature. While Jankowski et al. [31], after a double foliar application with boron, increased the protein content in seeds by an average of $8.8 \mathrm{~g} \cdot \mathrm{kg}^{-1}$ of d.m. compared to the control object. In regards to seed protein, the present study's research showed the interaction of the types of biostimulators used in relation to the protein content in the seeds of the rapeseed morphotype varieties studied, which indicated the individual response of the rapeseed varieties to the biopreparations used (Table 2). The lowest protein was in the treatment of Konkret with Silvit and PX104 with Silvit, and in Pozniak with Tytanit. In all morphotypes, the highest protein content was recorded on the object where no natural growth stimulants were used. In the cultivar with the traditional growth type, the lowest protein content was found after the application of the Tytanit biostimulator, while in the other varieities it was after the use of the Silvit biostimulator. Equal protein content was found in the restored hybrids of the semi-dwarf type (PX104) after the application of the Asahi SL and Tytanit preparations. A similar tendency was observed in the restored hybrid with the traditional growth type.

The content of total seed protein was dependant on the genetic factor (Table 2). In our own research, the content of protein in the seeds of the studied winter rape varieties averaged from 361.37 to $373.42 \mathrm{~g} \cdot \mathrm{kg}^{-1}$ of d.m. The highest concentration was found in the semi-dwarf hybrid PX104, while in the long-stem hybrid (Konkret), it was lower on average by $12.05 \mathrm{~g} \cdot \mathrm{kg}^{-1} \mathrm{of} \mathrm{d} . \mathrm{m}$. Different results were obtained by Gugała et al. [25], who received the highest value of this feature in a hybrid with a traditional type of growth and the lowest in a semi-dwarf hybrid. Ratajczak et al. [32] did not show significant differences between heterosis morphotypes with a traditional and semi-dwarf type of growth or in the population Califorium variety.

\subsection{The Content of Crude Fat Depending on the Types of Biostimulators Used}

The bioregulators used in the experiment significantly influenced the increase of crude fat in winter rapeseeds (Table 2). The greatest value of this feature was noted after the use of the Asahi SL biostimulator, it was significantly smaller on the objects where Tytanit and Silvit were applied. The beneficial effect of the Asahi SL biostimulator on the fat content in seeds was also confirmed by Spychaj-Fabisiak et al. [33] and Gugała et al. [25]. Similarly, Kováčik et al. [34] confirmed that a two-fold application of the Tytanit biostimulator affected the increase of the fat content in rapeseeds compared to the control object. The lack of effect of biostimulators on the fat content in seeds has been demonstrated by Matysiak et al. [29,30]. The authors observed only a slight tendency to increase the value of this feature even by $3.9 \%$ in relation to the control object. Similarly, Szczepanek et al. [35] noted a small effect of stimulating plant preparations on this feature. Jankowski et al. [31] after using a boron-containing foliar preparation, found a significant increase in the content of crude fat only after its two applications in the BBCH50 and BBCH55 phases. Jarecki and Bobrecka-Jamro [25,26] did not prove the effect of foliar preparations containing micro- and macro-elements on the value of this feature.

The impact of the types of biostimulators used on the crude fat content in rapeseed depended on the genetic factor (as shown in Table 2). The lowest fat content in all tested cultivars was recorded on the control object. The population cultivar had the highest fat content after using the Asahi SL biostimulator, but after the application of all biopreparations in this cultivar, the differences in protein crude fat content were not statistically significant. The seeds of the restored hybrid with the traditional 
growth type were characterized by the highest content of crude fat after the application of Asahi $\mathrm{SL}$, and under the influence of the other biostimulators, they were the same as on the control object. A similar tendency was observed in the semi-dwarf hybrid, with differences in the value of this trait on the objects with the Tytanit and Silvit biostimulator were not statistically significant.

The content of crude fat depending on the genetic factor is shown in Table 2. Our own research proved that the highest content of fat was a characteristic of the PX104 (restored hybrid with a semi-dwarf type of growth), it was significantly smaller by $17.66 \mathrm{~g} \cdot \mathrm{kg}^{-1} \mathrm{of}$ d.m. in the long-stem hybrid (Konkret), while the smallest on average by $20.57 \mathrm{~g} \cdot \mathrm{kg}^{-1}$ was in the population form (Poznaniak). Different results of studies were obtained by Gugała et al. [25] who showed that the highest value of this feature was characteristic for a restored hybrid with a traditional type of growth, while the smallest the population (Monolit).

\subsection{The Content of Crude Fibre Depending on the Types of Biostimulators Used}

Natural plant preparations influenced the increase of the crude fibre content in winter oilseed rapeseeds on average from 0.15 to $0.84 \mathrm{~g} \cdot \mathrm{kg}^{-1} \mathrm{of} \mathrm{d} . \mathrm{m}$. (Table 2). The highest value of this feature was noted on object 3 with the Asahi SL biostimulator. Different results were obtained by Gugała et al. [25]. In this study, the biostimulants did not significantly alter the crude fibre content in seeds of the rapeseed cultivars (Table 2).

The content of crude fibre depending on the genetic factor is shown in Table 2. Our own studies indicate that the highest content of crude fibre was observed in the seeds of the PX104 variety, while the smallest was in the long-stem morphotype (Konkret). Different results were obtained by Gugała et al. [25], who did not find any statistical differences in the value of this feature between the studied morphotypes.

\subsection{Chemical Composition Depending on Weather Conditions}

The chemical composition of seeds depending on climatic conditions in the study years is shown in Table 2. In our own research, the highest content of total protein, fat and crude fibre was obtained in seeds collected in the second year of research, in which the total precipitation was $41.9 \mathrm{~mm}$ higher in May, and the average monthly temperature was smaller by $0.5^{\circ} \mathrm{C}$ from the average multi-year. Similar results were obtained by Chmura et al. [36] and Gugała et al. [25]. According to the authors, during the period from the end of flowering to the technical maturity stage of high protein content, temperatures of $16.2^{\circ} \mathrm{C}$ were maintained on average, regardless of the sum of rainfall. Maczyńska et al. [37] recorded a higher concentration of fat in colder years with a greater sum of precipitation, while it was lower in warm years. In our own studies, differences in the content of total protein and crude fat in the growing season of 2013-2014 and 2015-2016 were statistically insignificant, while the lowest content of crude fibre was found in seeds collected in the first year of research. 
Table 2. Chemical composition of winter oilseed rapeseeds depending on factors of experience.

\begin{tabular}{|c|c|c|c|c|c|c|c|c|}
\hline \multirow{4}{*}{ Culticars } & \multirow{3}{*}{\multicolumn{2}{|c|}{ Years }} & & \multicolumn{4}{|c|}{ Types of Biostimulators Used } & \multirow{4}{*}{ Mean } \\
\hline & & & & \multicolumn{4}{|c|}{ Objects } & \\
\hline & & & & 1. & 2. & \multirow{2}{*}{$\begin{array}{c}3 . \\
\text { Asahi }^{\circledR} \mathrm{SL}\end{array}$} & \multirow{2}{*}{$\frac{4 .}{\text { Silvit }^{\circledR}}$} & \\
\hline & 2013-2014 & 2014-2015 & 2015-2016 & Control Variant & Tytanit $^{\circledR}$ & & & \\
\hline \multicolumn{9}{|c|}{ Total protein $\left[\mathrm{g} \cdot \mathrm{kg}^{-1}\right.$ d.m] } \\
\hline Poznaniak & 370.92 & 372.80 & 370.78 & 372.18 & 370.71 & 371.83 & 371.27 & $371.50 \mathrm{a}$ \\
\hline Konkret & 357.84 & 367.64 & 358.62 & 362.79 & 361.26 & 361.33 & 360.09 & $361.37 \mathrm{~b}$ \\
\hline PX104 & 373.13 & 374.33 & 372.81 & 374.11 & 373.62 & 373.49 & 372.46 & $373.42 \mathrm{c}$ \\
\hline Mean & $367.29 a$ & $371.59 \mathrm{~b}$ & $367.40 \mathrm{a}$ & $369.69 a$ & $368.53 \mathrm{ab}$ & $368.89 \mathrm{bc}$ & $367.94 \mathrm{~d}$ & \\
\hline \multicolumn{9}{|c|}{$\mathrm{LSD}_{0.05}$ for: years -0.68 ; cultivars -0.68 ; types of biostimulators used -0.52 ; interaction: years $\mathrm{x}$ cultivars -1.18 ; cultivars $\mathrm{x}$ types of biostimulators used-0.82 } \\
\hline \multicolumn{9}{|c|}{ Crude fat $\left[\mathrm{g} \cdot \mathrm{kg}^{-1} \mathrm{~d} . \mathrm{m}\right]$} \\
\hline Poznaniak & 468.98 & 470.43 & 469.43 & 468.88 & 469.71 & 470.10 & 469.77 & $469.61 \mathrm{a}$ \\
\hline Konkret & 472.33 & 472.93 & 472.30 & 472.00 & 472.41 & 473.14 & 472.53 & $472.52 b$ \\
\hline PX104 & 489.78 & 490.70 & 490.06 & 488.78 & 489.64 & 492.19 & 490.10 & $490.18 \mathrm{c}$ \\
\hline Mean & $477.03 a$ & $478.02 \mathrm{~b}$ & $477.26 \mathrm{a}$ & $476.55 a$ & 477.26be & $478.48 \mathrm{~d}$ & 477.47ce & \\
\hline \multicolumn{9}{|c|}{$\mathrm{LSD}_{0.05}$ for: years -0.35 ; cultivars -0.35 ; types of biostimulators used-0.52; interaction: years $\mathrm{x}$ cultivars-n.s.; cultivars $\mathrm{x}$ types of biostimulators used-0.5. } \\
\hline \multicolumn{9}{|c|}{ Crude fiber [g.kg-1 d.m] } \\
\hline Poznaniak & 89.31 & 90.19 & 89.73 & 89.40 & 89.70 & 90.32 & 89.56 & $89.74 a$ \\
\hline Konkret & 85.28 & 86.11 & 85.58 & 85.41 & 85.70 & 86.02 & 85.49 & $85.66 \mathrm{~b}$ \\
\hline PX104 & 69.48 & 70.44 & 70.09 & 69.61 & 70.00 & 70.58 & 69.82 & $70.00 \mathrm{c}$ \\
\hline Mean & $81.36 a$ & $82.25 b$ & $81.80 \mathrm{c}$ & $81.47 a$ & $81.80 \mathrm{~b}$ & $82.31 \mathrm{c}$ & $81.62 \mathrm{~d}$ & \\
\hline
\end{tabular}
n.s. - non-significant differences. Different letters above the bars denote significant differences $p \leq 0.05$. 


\section{Conclusions}

In summary, the applied biostimulators had an effect on reducing the total protein content (on average from 0.8 to $1.75 \mathrm{~g} \cdot \mathrm{kg}^{-1}$ of d.m.) and increasing the concentration of crude fat (on average from 0.71 to $1.93 \mathrm{~g} \cdot \mathrm{kg}^{-1}$ of d.m.) and crude fibre (on average from 0.15 to $0.84 \mathrm{~g} \cdot \mathrm{kg}^{-1}$ of d.m.) compared to the control object. The best quality of seeds was characteristic for the semi-dwarf PX104 variety. The smallest protein content was found in seeds of the long-stem hybrid Konkret, while crude fat was lowest in the population form (Poznaniak), and crude fibre was lowest in long-stem hybrid (Konkret). Diverse climatic conditions prevailing in the years of conducting the experiment influenced the chemical composition of rapeseeds. The highest content of total protein, crude fat and fibre were obtained in the second year of studies.

Author Contributions: Methodology, K.Z. and M.G.; software, M.G.; writing—original draft preparation, A.S.; review and editing-P.F. and U.M.-T.

Funding: The results of the research carried out under the research theme No. 363/S/13 were financed from the science grant granted by the Ministry of Science and Higher Education".

Conflicts of Interest: The authors declare no conflict of interest.

\section{References}

1. Kałużewicz, A.; Krzesiński, W.; Spiżewski, T.; Zaworska, A. Effect of biostimulants on several physiological characteristics and chlorophyll content in broccoli under drought stress and re-watering. Not. Bot. Horti Agrobo. 2017, 45, 197-202. [CrossRef]

2. Rouphael, Y.; Colla, G. Synergistic biostimulatory action: Designing the next generation of plant biostimulants for sustainable agriculture. Front. Plant Sci. 2018, 9, 1655. [CrossRef] [PubMed]

3. Wierzbowska, J.; Sienkiewicz, S.; Bowszys, T. Effect of growth regulators on the mineral balance in spring triticale. J. Elem. 2010, 15, 745-756. [CrossRef]

4. Marjańska-Cichoń, B.; Sapieha-Waszkiewicz, A. The effect of preparations Asahi SL and Tytanit on the growth and yielding of strawberry variety salut. Prog. Plant Prot. 2010, 50, 383-388. (In Polish)

5. Stadnik, M.J.; de Freitas, M.B. Algal polysaccharides as source of plant resistance inducers. Trop. Plant Pathol. 2014, 39, 111-118. [CrossRef]

6. Panda, D.; Pramanik, K.B.; Naya, R. Use of sea weed extracts as plant growth regulators for sustainable agriculture. Int. J. Stress Manag. 2012, 3, 404-411.

7. Sharma, S.H.S.; Fleming, C.; Selby, C.H.; Rao, J.R.; Trevor, M. Plant biostimulants: A review on the processing of macroalgae and use of extracts for crop management to reduce abiotic and biotic stresses. J. Appl. Phycol. 2014, 26, 465-490. [CrossRef]

8. Yakhin, O.I.; Lubyanov, A.A.; Yakhin, I.; Brown, P.H. Biostimulants in plant science: A global perspective. Front. Plant Sci. 2017, 7, 2049. [CrossRef]

9. Petrozza, A.; Santaniello, A.; Summerer, S.; di Tommaso, G.; di Tommaso, D.; Paparelli, E.; Piaggesi, A.; Perata, P.; Cellini, F. Physiological responses to Megafol ${ }^{\circledR}$ treatments in tomato plants under drought stress: A phenomic and molecular approach. Sci. Hortic. 2014, 174, 185-192. [CrossRef]

10. Colla, G.; Rouphael, Y. Biostimulants in horticulture. Sci. Hortic. 2015, 196, 1-2. [CrossRef]

11. Rouphael, Y.; de Micco, V.; Arena, C.; Raimondi, G.; Colla, G.; de Pascale, S. Effect of Ecklonia maxima seaweed extract on yield, mineral composition, gas exchange and leaf anatomy of zucchini squash grown under saline conditions. J. Appl. Phycol. 2017, 29, 459-470. [CrossRef]

12. Calvo, P.; Nelson, L.; Kloepper, J. Agricultural uses of plant biostimulants. Plant Soil 2014, 383, 3-4. [CrossRef]

13. El-Boray, M.S.; Mostafa, M.F.M.; Salem, S.E.; El-Sawwah, O.A.O. Improving yield and fruit quality of washington navel orange using foliar applications of some natural biostimulants. Int. J. Plant Prod. 2015, 6, 1317-1332. [CrossRef]

14. Przybysz, A.; Gawronska, H.; Gajc-Wolska, J. Biological mode of action of a nitrophenolates-based biostimulant: Case study. Front. Plant Sci. 2014, 5, 713. [CrossRef] 
15. Kocira, A.; Świeca, M.; Kocira, S.; Złotek, U.; Jakubczyk, A. Enhancement of yield, nutritional and nutraceutical properties of two common bean cultivars following the application of seaweed extract (Ecklonia maxima). Saudi J. Biol. Sci. 2018, 25, 563-571. [CrossRef]

16. Zulfiqar, F.; Casadesús, A.; Brockman, H.; Munné-Bosch, S. An overview of plant-based natural biostimulants for sustainable horticulture with a particular focus on moringa leaf extracts. Plant Sci. 2019. [CrossRef]

17. Grabowska, A.; Kunicki, E.; Sekara, A.; Kalisz, A.; Wojciechowska, R. The effect of cultivar and biostimulant treatment on the carrot yield and its quality. Veg. Crops Res. Bull. 2012, 77, 37-48. [CrossRef]

18. Kolomaznik, K.; Pecha, J.; Friebrova, V.; Janacova, D.; Vasek, V. Diffusion of biostimulators into plant tissues. Heat Mass Transf. 2012, 48, 1505-1512. [CrossRef]

19. Meier, U.; Bleiholder, H.; Buhr, L.; Feller, C.; Hack, H.; Heß, M. The BBCH system to coding the phenological growth stages of plants-history and publications. J. Kult. 2009, 61, 41-52.

20. World Reference Base for Soil Resources. International soil classification system for naming soils and creating legends for soil. In World Soil Resources Reports 106; Field Experiment; Food and Agriculture Organization: Rome, Italy, 2014; Available online: http://www.fao.org (accessed on 1 November 2019).

21. PN-ISO 6492:2005, Feed-Determination of fat content. Available online: http://sklep.pkn.pl/pn-iso-64922005p.html (accessed on 1 November 2019).

22. PN-EN ISO 5983-2:2009, Feed-Determination of nitrogen content and calculation of total protein content. Available online: https:/infostore.saiglobal.com/en-au/Standards/PN-EN-ISO-5983-2-2009-924549_SAIG_ PKN_PKN_2182095/ (accessed on 1 November 2019).

23. Trętowski, J.; Wójcik, R. Methodology of Agricultural Experiments; Wyższa Szkoła Rolniczo-Pedagogiczna: Siedlce, Poland, 1991; pp. 331-334. (In Polish)

24. Skowera, B. Changes of hydrothermal conditions in the Polish area (1971-2010). Fragm. Agron. 2014, 31, 74-87. (In Polish)

25. Gugała, M.; Sikorska, A.; Zarzecka, K.; Kapela, K.; Mystkowska, M. The effect of biostimulators on the content of crude oil and total protein in winter oilseed rape (Brassica napus L.) seeds. Acta Agric. Scand. Sect. B Soil Plant Sci. 2019, 69, 121-125. [CrossRef]

26. Jarecki, W.; Bobrecka-Jamro, D. Reaction of winter rape to the extra feeding of its leaves. Ann. UMCS Agric. 2008, 63, 86-96. [CrossRef]

27. Jarecki, W.; Bobrecka-Jamro, D. The reaction of the Huzar cultivar of spring oilseed rape to the density of sowing and to leaf feeding with urea. Rośliny Oleiste 2011, 32, 117-126. (In Polish)

28. Kozak, M.; Malarz, W.; Bzowy-Wójtowicz, A.; Białkowska, A. Influence of biostimulators on yield of winter rapeseed. In Proceedings of the Prosperující Olejniny, Prague, Czech Republic, 9-10 December 2010; pp. 67-69.

29. Matysiak, K.; Adamczewski, K.; Kaczmarek, S. Response of some crops cultivated in Great Poland to application of Asahi SL. Prog. Plant Prot. 2011, 51, 1849-1857. (In Polish)

30. Matysiak, K.; Kaczmarek, S.; Kierzek, R. Effect of algae Ecklonia maxima (Kelpak SL) on winter oilseed rape. Rośliny Oleiste 2012, 33, 81-88. (In Polish) [CrossRef]

31. Jankowski, K.J.; Sokólski, M.; Dubis, B.; Krzebietke, S.; Żarczyński, P.; Hulanicki, P.; Hulanicki, P.S. Yield and quality of winter oilseed rape (Brassica napus L.) seeds in response to foliar application of boron. Agric. Food Sci. 2016, 25, 164-176. [CrossRef]

32. Ratajczak, K.; Sulewska, H.; Szymańska, G. New winter oilseed rape varieties—Seed quality and morphological traits depending on sowing date and rate. J. Plant Prod. Sci. 2017, 20, 262-272. [CrossRef]

33. Spychaj-Fabisiak, E.; Murawska, B.; Pacholczyk, Ł. Values of quality traits of oilseed rape seeds depending on the fertilization and plant density. J. Elem. 2011, 16, 115-124.

34. Kováčik, P.; Šimanský, V.; Wierzbowska, J.; Renčo, M. Impact of foliar application of biostimulator Mg-Titanit on formation of winter oilseed rape phytomass and its titanium content. J. Elem. 2016, 21, 1235-1251. [CrossRef]

35. Szczepanek, M.; Wilczewski, E.; Grzybowski, K. Response of winter oilseed rape (Brassica napus L.) on soil applied humus preparation and foliar potassium fertilizer. Acta Sci. Pol. Ser. Agric. 2016, 15, 85-94. 
36. Chmura, K.; Dzieżyc, H.; Piotrowski, M. Influence of meteorological conditions on the fat and protein content in seed of winter oilseed rape. Acta Agrophys. 2016, 23, 163-173. (In Polish)

37. Mączyńska, A.; Krzyzińska, B.; Banachowska, J. Effect of fungicides applied the flowering stage of winter oilseed rape on the yield quantity and quality of seeds. Prog. Plant Prot. 2015, 55, 231-236. (In Polish)

(C) 2019 by the authors. Licensee MDPI, Basel, Switzerland. This article is an open access article distributed under the terms and conditions of the Creative Commons Attribution (CC BY) license (http://creativecommons.org/licenses/by/4.0/). 